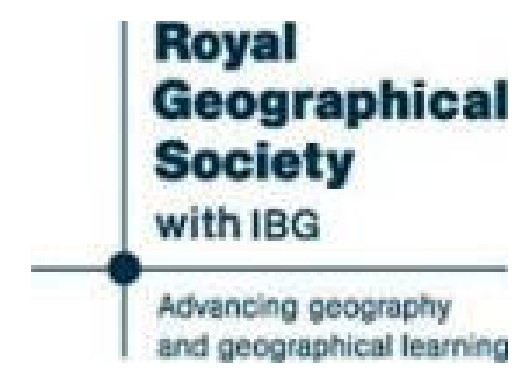

\title{
South Sea Art
}

Südseekunst. Beiträge zur Kunst des Bismarck-Archipels und zur Urgeschichte der Kunst überhaupt by Emil Stephan

Review by: A. C. Haddon

The Geographical Journal, Vol. 30, No. 2 (Aug., 1907), p. 205

Published by: The Royal Geographical Society (with the Institute of British Geographers)

Stable URL: http://www.jstor.org/stable/1776636

Accessed: 27/01/2015 08:23

Your use of the JSTOR archive indicates your acceptance of the Terms \& Conditions of Use, available at

http://www.jstor.org/page/info/about/policies/terms.jsp

JSTOR is a not-for-profit service that helps scholars, researchers, and students discover, use, and build upon a wide range of content in a trusted digital archive. We use information technology and tools to increase productivity and facilitate new forms of scholarship. For more information about JSTOR, please contact support@jstor.org. 
The classificatory system of kinship occurs, but no examples are given as to how it works out. No fresh light is cast upon the Dukduk secret society. Anthropometrical data are given of three individuals. A novel and interesting feature is a list of the people and their possessions (house, canoe, gardens, palms, pigs, fowls, dogs, and the like) in two villages. This idea night be copied and extended with advantage by other investigators. The essay by Dr. Graebner on the ethnographical position of the area in question is of considerable value; he is well qualified for the task, having recently published a valuable paper on "Culture Areas and Culture Layers in Oceania" (Zeitschr. für Ethnologie, 1905). By means of the map of distributions which he has compiled, one can see at a glance many of the affinities of the region in question. Maps of this kind afford a useful means of taking stock of our existing knuwledge, and serve to give coherence to scattered observations.

A. C. HADDON.

\section{South Sea Art.}

'Südseekunst. Beiträge zur Kunst des Bismarck-Archipels und zur Urgeschichte der Kunst überhaupt.' Von Dr. Emil Stephan. Berlin : D. Reimer (E. Vohsen). 1907. Price 6 marks.

Dr. Stephan's book has a double value to students. In the first place, it is the record of a careful investigator who gives us full and accurate representations of objects from definite localities in Southern New Ireland, and the meaning of their decoration; though even he admits that " among the explanations to the plates are a number of native names the meaning of which can be made out only imperfectly, or not at all, as well as many patterns the native names of which could not be discovered." In the second place, it is evident from his remarks how unsatisfactory it is for students at home to attempt to elucidate native designs without first-hand knowledge. Among the many interesting facts discovered by Dr. Stephan, we may note that the most important animals, the dog and the pig, are never represented in art. Birds are extremely frequent, especially the frigate bird. Human representations are common, but the sex element is almost entirely lacking, and woman herself and all that relates to her sex are altogether absent. Heavenly bodies are rarely depicted, but other phenomena receive a most unusual attention. For instance, on two boats phosphorescent waves are painted, and common on bamboo boxes are conventional engravings of landscapes, still deep water, rain over sea which is stirred by a gentle wind, and stormy sea and rocks when the seething water is tossed on high.

In the essay on the æsthetics of the Bismarck islanders we have the general conclusions of a field-worker. His remarks on his own area must carry weight, but some of his comparisons with other fields may require reconsideration. It is possible that, had time permitted him to gain a deeper insight into the social groupings and the magical and religious ideas of the people under consideration, he would have found a significance which has so often eluded him. We may allow that there is no profundity in the artistic representations of these people, but that is quite different from denying that there may be a depth of significance greater than their " face-value." Our knowledge of the art of other peoples certainly permits us to expect that this will probably be found to be the case here also. The closing remarks of this valuable contribution to ethnography form an earnest appeal for further investigation by the German Government. The author also rightly says, "Instead of collections, let observations be our watchword, for books of careful notes are a far more valuable production of travel than great cases full of hastily collected objects."

$$
\text { A. C. HadDon. }
$$

